\title{
Birgitta of Sweden and her Pilgrimage to Santiago de Compostela
}

\section{Salmesvuori, Päivi}

Ashgate

2015

Salmesvuori, P 2015 , Birgitta of Sweden and her Pilgrimage to Santiago de Compostela . in C A Gonzáles-Paz (ed.), Women and Pilgrimage in Medieval Galicia ., 7 , Compostela pÿInternational Studies in Pilgrimage History and Culture, Ashgate, Farnham, pp. 113121.

http://hdl.handle.net/10138/340797

cc_by_nc

publishedVersion

Downloaded from Helda, University of Helsinki institutional repository.

This is an electronic reprint of the original article.

This reprint may differ from the original in pagination and typographic detail.

Please cite the original version. 


\title{
Chapter 7
}

\section{Birgitta of Sweden and her Pilgrimage to Santiago de Compostela}

\author{
Päivi Salmesvuori
}

The only canonized saint of Scandinavia is the aristocratic lady Birgitta of Sweden ${ }^{1}$ (1302/1303-73). In 1999 Pope John Paul II proclaimed St Birgitta of Sweden, St Catherine of Siena and St Teresa Benedicta of the Cross co-patronesses of Europe. This proclamation was part of the Great Jubilee of the Year 2000. The Pope explained this act as 'completing' what he had done in 1980 when he had declared St Benedict and the saintly brothers Cyril and Methodius as co-patrons of Europe. The three women were according to the Pope 'outstanding for their fruitful love of Christ's Church and their witness to His Cross. ${ }^{2}$ However, the beginning of Birgitta of Sweden's sainthood was far from an easy endeavour. The living saint herself, Birgitta, and after her death her close supporters had to work hard to have her canonized, which eventually happened in 1391. For a saint in spe a virtuous life and saintly fame were important prerequisites. In Birgitta of Sweden's canonization process an important part of her saintly virtue was her reputation as a tireless pilgrim. This chapter will explore the beginning of Birgitta's saintly career and the role that pilgrimage to Santiago de Compostela played in it. Initially it will briefly sketch the context from which Birgitta came.

\section{Birgitta's Sweden}

Birgitta's family belonged to the highest aristocracy of Sweden. Her father, Birger Petersson, was probably born in 1265 . He was a knight and a lawman,

Also known as [St] Bridget of Sweden [editor's note].

2 Pope John Paul II, Apostolic letter issued 'motu proprio' proclaiming St Bridget of Sweden, St Catherine of Siena and St Teresa Benedicta of the Cross co-patronesses of Europe (Rome, 1 October 1999), ed. Libreria Editrice Vaticana, at http://www.vatican.va/holy father/john_paul_ii/motu_proprio/documents/hf_jp-ii_motu-proprio_01101999_copatronesses-europe_en.html (accessed 20 January 2013). 
a politician and a councillor of state. Birgitta's mother, Ingeborg Bengtsdotter (b. after 1275), was Birger's second wife. She was related to the Folkung dynasty and her father, Bengt, as were many other men in her family, was also a lawman. ${ }^{3}$

Birgitta was given in marriage in 1316 when she was around 14 years old, a couple of years after her mother's death. ${ }^{4}$ Birgitta's husband Ulf Gudmarsson was about five years older than Birgitta. Ulf followed his father's example and became a lawman and knight. He also belonged to the council of state. His work not only concerned legislative matters, but also required him to travel with the king and his court around the kingdom. ${ }^{5}$ This provided important contacts for Birgitta too, both as a noblewoman and as a visionary.

Birgitta and Ulf had eight children. The oldest, possibly a son named Gudmar, was born around 1318 and the youngest, Cecilia, was probably born between the years 1334 and 1337. The other children, Märta, Karl, Ingeborg, Katarina, Birger and Bengt, were born between those years. Gudmar and Bengt died as children, and Ingeborg also died quite young. ${ }^{6}$

The beginning of the 1340 s witnessed a new phase in the life of the aristocratic couple. Although Birgitta and Ulf were busy with their daily duties, they also arranged time for pilgrimage. In 1341, they made the long pilgrimage to Spain, to Santiago de Compostela. ${ }^{7}$ Around 1344 Ulf died and Birgitta lived for long periods in the vicinity of the Cistercian monastery at Alvastra. Birgitta was not living the life of an enclosed nun but was in lively contact with the people around her. Her networks of contacts can be traced clearly from her revelations. At this time, when Birgitta was in her early forties, she started to experience more and more revelations which were written down in Latin by her collaborators. ${ }^{8}$

3 B. Klockars, Birgittas svenska värld (Stockholm: Natur och Kultur, 1976), pp. 24-6; B. Morris, St. Birgitta of Sweden, Studies in Medieval Mysticism, 1 (Woodbridge: Boydell Press, 1999), p. 32.

4 Klockars, Birgittas, p. 29; Morris, St. Birgitta, p. 30.

5 Lawmen were experts in matters of jurisdiction and were supposed to memorize the law. They were also in charge of the codification of provincial laws, which began at the end of the thirteenth century. Around 1347, during King Magnus Eriksson's reign, Sweden got its first landslag (state law). Klockars, Birgittas, pp. 67-75.

6 Ibid., pp. 93-100.

7 On Scandinavian pilgrimages, see C. Krötzl, Pilger, Mirakel und Alltag. Formen des Verhaltens im skandinavischen Mittelalter (12.-15. Jahrhundert), Studia Historica, 46 (Helsinki: Suomalaisen Kirjallisuuden Seura, 1994).

8 For the beginning of Birgitta's visionary career, see P. Salmesvuori, Power and Sainthood. The Case of Birgitta of Sweden (New York: Palgrave Macmillan, 2014). On Birgitta and her prophetic authority, see C.L. Sahlin, Birgitta of Sweden and the Voice of Prophecy, Studies in Medieval Mysticism, 3 (Woodbridge: Boydell Press, 2001). 
In the twelfth and thirteenth centuries in Sweden, the State and Church were relatively recent phenomena and were only gradually taking shape.9 ${ }^{9}$ The Church's activities were changing from a missionary character to something closely resembling an established institution. Clerics were educated in continental universities such as Paris and Cologne; in the fourteenth century Prague also became a popular place of education. ${ }^{10}$ Consequently, influences from abroad were strong.

Gradually, in the thirteenth century the institutions of State and Church in Sweden grew more powerful and stable, their mutual relationship developing apace. Frequent power struggles occurred but they also found allies in each other. The Cistercians, Franciscans and Dominicans established their houses in Sweden during the thirteenth century, and the Church not only grew into a powerful institution but also became one of the largest landholders." Meanwhile, the nature of kingship was changing. In the thirteenth century, the King of Sweden was itinerant and often travelled through the country with his retinue. On their journeys, the king and his men had the right to demand hospitality from their subjects. On the one hand, this strengthened the court's relations with the aristocracy but on the other, the demand for hospitality was regarded as a burden. ${ }^{12}$

In other European countries the burghers were often useful supporters of the nobility and monarchy, but in thirteenth- and fourteenth-century Sweden, it was the farmers who played this role. It was characteristic of Swedish society that, as Bridget Morris puts it, it 'was divided into those who paid taxes, mainly

9 Regarding medieval Scandinavia in general, see B. Sawyer and P.H. Sawyer, Medieval Scandinavia: From Conversion to Reformation, circa 800-1500, The Nordic Series, 17 (Minneapolis: University of Minnesota Press, 1993). For the politics and administration of Sweden and Norway in the fourteenth century, see G.A. Blom, Norge $i$ union pa 1300-tallet. Kongedomme, politikk, administrasjon og forvaltning 1319-1380 (2 vols, Trondheim: Tapir Forlag, 1992).

10 J. Nuorteva, Suomalaisten ulkomainen opinkäynti ennen Turun akatemian perustamista 1640, Suomen Kirkkohistoriallisen Seuran Toimituksia 177, Bibliotheca historica 27 (Helsinki: Suomalaisen Kirjallisuuden Seura, 1997), pp. 36-65.

"I B. Nilsson, Sveriges kyrkohistoria. 1. Missionstid och tidig medeltid (Stockholm: Verbum i samarbete med Svenska kyrkans forskningsråd, 1998), pp. 98-110; Morris, St. Birgitta, pp. 26-8.

12 B. Klockars, Biskop Hemming av Ảbo, Skrifter utgivna av Svenska litteratursällskapet i Finland, 379 (Helsingfors: Svenska litteratursällskapet i Finland, 1960), pp. 94-6; Morris, St. Birgitta, p. 24; S.E. Pernler, Sveriges kyrkobistoria. 2. Hög-och senmedeltid (Stockholm: Verbum, 1999), pp. 92-3. 
the free farming class, and those who did not, mainly the nobles, their tenants, and the crown's tenants.' ${ }^{13}$

King Magnus Eriksson attained his majority in 1332 and was crowned four years later as the king of three regions, Sweden, Norway and Skåne. The king ruled with the help of the Council of State. Besides the secular administrators, the Council consisted of the archbishop as the highest ranked member, other bishops and clergy, and usually 12 members of the aristocracy. ${ }^{14}$ This meant that the Church and the aristocracy were in charge of the political decisionmaking together with the king. Birgitta's husband Ulf belonged to the king's closest advisors. When the king was to marry the foreign princess Blanche of Namur, Birgitta apparently acted as the future queen's mentor. ${ }^{15}$ Thus both Ulf and Birgitta knew the royal couple well and they had many common interests. In other words, Birgitta's life was busy both at home and at work. After the birth of her youngest child Cecilia around 1337, however, a change seems to have occurred. One sign of this was Birgitta's growing interest in pilgrimages.

\section{The Role of the Santiago Pilgrimage in Shaping Birgitta's Saintly Fame}

In the fourth year before her [Birgitta's] husband's passing, a saint of our land of Sweden, Botvid by name, appeared to her, as it were, in an ecstasy of mind, and said: 'I have, with other saints, merited for you God's grace - namely, to hear and to see and to feel spiritual things - and the Spirit of God will inflame your soul. ${ }^{16}$

The quotation above from the beginning of Birgitta's Vita describes aptly the extraordinary gift Birgitta had: to hear, see and feel spiritual things. As a result of this she produced a vast corpus of revelations, almost seven hundred of them. Botvid (d. 1100), the saint speaking to Birgitta in the passage above, was a lay saint widely known and venerated in Sweden. Thus it seems very natural that he would contact another chosen Swede in a vision, as if contacting his successor.

13 Morris, St. Birgitta, p. 26.

14 The sources from this time are far from complete. Therefore, it is not quite clear how the administration was organized during Magnus's minority. Blom, Norge, pp. 40-43.

15 Salmesvuori, Power, p. 28.

16 'Vita b. Brigide prioris Petri et magistri Petri', Acta et processus canonizacionis beate Birgitte, ed. I. Collijn, Samlingar utgivna av Svenska fornskriftsällskapet, Ser. 2 (Latinska skrifter), vol. 1 (Uppsala: Almqvist and Wiksells Boktryckeri, 1924-31), p. 81; 'Life of Blessed Birgitta. By Prior Peter and Master Peter', Birgitta of Sweden, Life and Selected Revelations, ed. M.T. Harris and trans. A.R. Kezel (New York: Paulist Press, 1990), pp. 69-98. 
Usually, Birgitta saw or heard saints speaking to her near places that had been important for those saints or their cults. This appearance of Botvid occurs around the time when Birgitta made a pilgrimage to the grave of $\mathrm{St}$ Olaf, another Scandinavian buried in Nidaros. Birgitta made this pilgrimage on foot, at least according to the testimony of her daughter Katarina in the acts of canonization. Katarina also said that Birgitta had friends and servants with her on the trip, though her husband Ulf is not mentioned as having been present. ${ }^{17}$

Going on pilgrimages was typical of wealthy people in medieval Europe and Christianized Scandinavia also followed this trend. A good Christian should arrange his or her life so that at some point, he or she could perform a longer pilgrimage. ${ }^{18}$ Parents often set a pilgrimage pattern that their children followed. In Birgitta's Vita, it is said that Birgitta's father, lawman Birger, went to Santiago de Compostela 'imitating the footsteps of his predecessors. For his father had been a Jerusalem pilgrim and so had his grandfather and his great-grandfather and his great-great-grandfather. ${ }^{19}$ Hence it was to be expected of Ulf as a lawman and of Birgitta as his devout wife to go on pilgrimage. The authors of the Vita describe those times as follows:

When, however, Lady Birgitta had for a long time been making progress in the virtues, she also gained her husband for God. For even though he was a vigorous man and an important member of the king of Sweden's council, he occupied himself - at his wife's advice and admonishment - in learning to read the Hours of the most Blessed Virgin Mary and the books containing the laws and legal judgments; and he studied to fulfill what belongs to justice and the law. And so, both of them - namely, this husband and wife - being fervent in their love for God and that they might more freely disengage themselves from the vanities of the world, went forth from their fatherland and from their kindred after Abraham's example, and, with great labours and expenses, proceeded into Spain to Saint James in Compostela. ${ }^{20}$

The description says that Birgitta had already been spiritually active for a long time and she had even guided her husband in reading religious books. For the

17 'Vita', p. 309.

19 Krötzl, Pilger, pp. 99-102.

'Vita', p. 71; Life, p. 71. Katajala-Peltoma Miracles and Daily Life: The Evidence of tradition. See S. Katajala-Peltomaa, Gender, Miracles and Daily
Fourteenth-Century Canonization Processes, History of daily life (800-1600), 1 (Turnhout: Brepols, 2009).

20 'Vita', p. 79; Life, pp. 76-7. 
Vita, the growth of Ulf's religiosity is an important issue. Obviously Birgitta influenced her husband considerably in many matters. Nevertheless, it is hard to say whether the decision to go on pilgrimage was a mark of the 'conversion' of Ulf or if he was of an appropriate age and situation to do what he was expected to do as a noble lawman. Apparently Ulf Gudmarsson gave up his office as lawman before the journey. ${ }^{21}$

Ulf was in his forties and Birgitta in her late thirties when they went to Santiago de Compostela in the summer of 1341 . The couple travelled with other Swedish aristocrats and at least one cleric, a Cistercian from the monastery of Varnhem named Svennung. He acted as confessor to the participants. Besides Birgitta and Ulf, he is the only one whom the source mentions by name. ${ }^{22}$

The events of the journey are known only in part. When the Swedish group of pilgrims was travelling home through France, Ulf fell ill and they stayed in the city of Arras. Birgitta was praying for her husband's life when St Denis, the patron saint of France, appeared to her. He proclaimed to Birgitta the will of God, stating that through her God wanted his will to be made known to the world. As a sign of that promise, St Denis told Birgitta that her husband would not die in France of his present sickness. Another promise was also made to Birgitta in Arras. She received a vision according to which she would travel to Rome and to Jerusalem. ${ }^{23}$ After a long convalescence, Ulf's condition improved and the travellers returned to Sweden in the spring of $1342 .{ }^{24}$

According to the Vita, after the trip to Spain the noble couple agreed to live in a chaste marriage and enter a monastery, not an unusual decision in those days. ${ }^{25}$ However, it may be that the Vita is exploiting a hagiographical 'topos'.

21 Klockars, Birgittas, pp. 87-91.

22 'Deposicio copiosissima domini [Petri Olavi] prioris de Aluastro, facta in curia Romana', Acta et processus canonizacionis beate Birgitte, p. 503; Birgitta of Sweden, Reuelaciones, book VI, ed. B. Bergh, Samlingar utgivna av Svenska fornskriftsällskapet, Ser. 2 (Latinska skrifter), vol. 7/6 (Stockholm: Almqvist and Wiksell International, 1991), rev. no. 36.

23 Birgitta of Sweden, Reuelaciones Extrauagantes, ed. L. Hollman, Samlingar utgivna av Svenska fornskriftssällskapet, Ser. 2 (Latinska skrifter), vol. 5 (Uppsala: Almqvist and Wiksell Boktryckeri, 1956), p. 92; 'Vita', p. 80.

${ }^{24}$ Klockars, Birgittas, p. 90.

25 'Vita', p. 80. Here is again a hint of Birgitta's associative logic. St Denis, a French saint, appeared to her in France. She contextualized saints strongly to the places they were associated with in their vitae. For the concept and medieval examples of chaste marriage, see especially D. Elliott, Spiritual Marriage: Sexual Abstinence in Medieval Wedlock (Princeton, NJ: Princeton University Press, 1993). 
The last time Ulf appears in the Vita concerns his death, which is stated to have happened probably in $1344 .{ }^{26}$ It is easy to guess that Ulf did not quite recover from the illness he had suffered on the pilgrimage to Santiago de Compostela and he died less than two years after their return. Katarina, the daughter of Birgitta and Ulf, maintained in Birgitta's canonization acts that Ulf died before he could fulfill his promise to enter a monastery. The reason she gave was that the building of the monastery in question was not yet finished. ${ }^{27}$

The pilgrimage must have made the couple famous and appreciated in other people's eyes. It was in itself apparently a small miracle that they came back at all. ${ }^{28}$ In his study of the sociology of medieval pilgrimage, Lutz Kaelber notes that especially for religious virtuosi, who were often mendicant brothers, pilgrimages themselves could be seen as a 'means to display signs of sainthood'. ${ }^{29}$ The same phenomenon could be seen at work with Birgitta as well. Pilgrimage was part of her way to become a 'religious virtuoso'. Birgitta's vision of St Denis was obviously written down and told to everyone - it was in the nature of prophecies that they should be made public. Hence Birgitta's fame continued to increase.

After her husband's death Birgitta felt a strong call to become the bride of Christ. Nevertheless, she struggled with the fact that she had been a married woman and was the mother of eight children. She knew the popular book Speculum virginum well, the teachings of which could also be described as a eulogy for female virginity. ${ }^{30}$ One part of compensating this shortage was to shape the reputation of her husband in a more pious direction. Here mutual pilgrimage played an important role. She was assisted in this through a vision that she experienced a short time after Ulf's death. The core of the story is Ulf's eternal destiny but it reveals many interesting events from his life. This vision is presented in chapter 56 of the Extravagantes. The vision may make references to Ulf's will which has not been found but which he probably had drawn up as was customary for people of his rank. ${ }^{31}$ In the vision, Ulf complains that he had done wrong in five matters before his death. He says that after a short time in Purgatory he is about to arrive in Heaven and in order to do so he needs help from Birgitta.

26 Salmesvuori, Power, pp. 36-7.

27 Acta, p. 305.

28 Regarding medieval travellers' final journey, see M.W. Labarge, Medieval Travellers: The Rich and Restless (London: Hamish Hamilton, 1982), p. 195.

29 L. Kaelber, "The Sociology of Medieval Pilgrimage: Contested Views and Shifting Boundaries', in W.H. Swatos, Jr. and L. Tomasi (eds), From Medieval Pilgrimage to Religious Tourism: The Social and Cultural Economics of Piety, Religion in the Age of Transformation, 13 (Westport, Conn.: Praeger, 2002), pp. 51-73.

30 Salmesvuori, Power, pp. 41-2.

31 Klockars, Birgittas, pp. 101-2. 
According to the revelation, Ulf had arrived in Purgatory and listed the reasons why he was being punished. Birgitta asked - as if slightly surprised that Ulf had gone to Purgatory and not to Hell - what deeds had been counted in his favour. Ulf mentioned six meritorious deeds. First, he had made his confession every Friday. Second, he had been an honest lawman and willing to correct his mistakes. Third, he refrained from sex with his wife as soon as he realized she was pregnant. Fourth, he had shown hospitality to the poor and did not have debts. Fifth, during the pilgrimage to Spain he drank nothing between resting places - this also compensated for his long dinners, excessive drinking, eating and talking at the table. The sixth merit was that he gave his position as a lawman to a person whom he knew would be just. After giving this list, Ulf asked Birgitta to shorten his time in Purgatory by having masses celebrated, taking care of the poor, having chalices made and distributing their property to their children. ${ }^{32}$

It is understandable that Birgitta was concerned about what would happen to her husband after his death. The vision revealing that Ulf was in Purgatory and waiting to get out was very comforting. His admission into Purgatory was already a relief. In order to reassure Birgitta, or the reader, the vision contained a list of Ulf's meritorious deeds so that it seemed credible that he would eventually get to Heaven. It also gave Birgitta the authority to decide, within a certain framework, how to dispose of the earthly goods of her husband. Obviously the framework was in accordance with what Birgitta thought was right, and what also could be presented as pious practices to be emulated by others.

When listing the good deeds of Ulf the vision reveals some interesting features about his life, or at least how Birgitta saw him. For example, he was honest in his job and wanted to do his best. He was also ready to change his judgment if necessary. He did not have sex with Birgitta once he knew she was pregnant, as was correct according to the doctrine of the Church, for sex was allowed only in order to beget children. Because of the public office Ulf had held, he was very well known and his nature and even his table manners were familiar to many. In the revelation, he said that he used to enjoy meals for many hours, and drink and eat too much. But this was forgiven, as was his loquaciousness, because he did not drink while on pilgrimage. No doubt, this kind of lifestyle also represents an ideal Christian aristocrat in Sweden in the fourteenth century.

This revelation was important for Birgitta's fama. It reshaped the image of Ulf after his death and showed him to be a kind-hearted and pious husband. If one considers that the revelation was also read or heard by people who had known Ulf personally, one can only admire how skilfully Birgitta's husband is

32 Birgitta, Reuelaciones Extrauagantes, chapter 56. 
transformed from a merry gastronome to a person who was just in his job and piously followed the commandments of the Church. After his death he thus became a suitable husband for the potential saint.

This small glimpse of the beginning of Birgitta of Sweden's saintly life shows that the pilgrimage to Santiago de Compostela played a decisive role in constructing Birgitta's saintly fame. The long and slow pilgrimage through Europe to Santiago de Compostela and back to Sweden brought about a change in Birgitta. In France she had seen people suffer from the ongoing war between England and France. ${ }^{33}$ In one of her revelations she prayed for the Virgin Mary and $\mathrm{St}$ Denis to have mercy on the people in France: 'For you see how the souls are in danger every hour, how people's bodies are thrown to the ground as if they were beasts. And what is even worse, their souls fall into Hell like snow. ${ }^{34}$ The quotation aptly describes Birgitta's continuous concern for people's souls. This led her to undertake a pilgrimage to Rome in 1349 and later in the 1370s to the Holy Land. In many fifteenth-century pictures of Birgitta her attributes are often a pilgrim staff, a hat and a pouch. After her canonization in 1391 she inspired many other women such as Margery Kempe to embark on pilgrimages.

33 Later this war was called the Hundred Years War. It began in 1337.

34 Birgitta of Sweden, Reuelaciones, book IV, ed. H. Aili, Samlingar utgivna av Svenska fornskriftsällskapet, Ser. 2 (Latinska skrifter), vol. 7/4 (Göteborg: Graphic Systems, 1992), rev. no. 103 (the author's translation). 